\title{
Main authors and contributors
}

\section{Main authors}

Jessica van den Bosch is managing director of the Tilburg Center of Entrepreneurship and a fellow of the Corporate Entrepreneurship Research Center, both located at Tilburg University in the Netherlands. Jessica studied law at Leiden University and has an MBA from Keele University (UK). Jessica is interested in the combination of management dynamics, professional practice and corporate entrepreneurship.

Geert Duysters is a full professor of entrepreneurship and innovation at Tilburg University. He acts as the scientific director of the Tilburg Center of Entrepreneurship. His academic research mainly concerns innovation strategies, mergers and acquisitions, corporate entrepreneurship and strategic alliances. He has published over 100 international refereed articles and six books on corporate innovation.

\section{Contributors}

Arjan van den Born is professor of entrepreneurship and creativity at Tilburg University. He acts as the director of the Creativity Entrepreneurship Lab. His academic research mainly concerns entrepreneurship, creativity, networks, communities and organizational change. He has published various international refereed articles and various books.

Victor Gilsing is a full professor of corporate innovation and entrepreneurship at University of Antwerp (Prinsstraat 13, 2000 Antwerpen) and Tilburg University. He acts as the co-leader of ACED, a research institute for organization and innovation at Antwerp University, and is also one of the core fellows of the Center for Innovation Research at Tilburg University. He has published in various top academic journals, such as Journal of Management, Journal of Management Studies, Research Policy, Technovation and others. Furthermore, he regularly teaches for senior executives, CFOs and both corporate and independent venture managers. 
Stijn van den Hoogen lectures on entrepreneurship and strategic management at Tilburg University. He is working on his $\mathrm{PhD}$ on the topic of corporate venturing, which is also his main research area. 
Jessica van den Bosch and Geert Duysters - 9781783476602 Downloaded from PubFactory at $04 / 26 / 2023$ 02:17:13PM via free access 